\title{
Poppies, Bloom
}

\section{Tommaso Lupia ${ }^{1}$ (D) . Giacomo Stroffolini ${ }^{1}$ · Francesco G. De Rosa ${ }^{1}$}

Accepted: 7 April 2021 / Published online: 7 July 2021

(c) The Author(s), under exclusive licence to Springer Science+Business Media, LLC, part of Springer Nature 2021

In spite of everything, I shall rise again; I will take up my pencil, which I have forsaken in my great discouragement, and I will go on with my drawing.

Vincent Van Gogh

To Luigi and to the other survivors of COVID-19

Fog looms behind this mask;

Even my mind is clouded.

I've been hearing so much about

$$
\text { oxygen }
$$

volumes

$$
\text { respiratory rates }
$$

scores...

How many weeks has it been?

I had that job to deliver

My arms are so numb...

Maybe I'll message him after.

Even as I rest,

I find myself wondering if I miss it:

the feel of the pages,

the smears of ink,

Tommaso Lupia

tommaso.lupia89@gmail.com

1 Department of Medical Sciences, Infectious Diseases, University of Turin, Turin, Italy 
the smell of fresh coffee.

I've been drawing for fifty years.

I've never spent so long without a pencil in hand.

How many hours has it been?

No, how many days?

When masked, they all look the same.

And, in this room,

Everyone seems to know me. They call me.

I share my grandfather's name, and now I miss my breath,

I miss my breath as he did in early spring when the poppies bloomed.

I miss the poppies.

Shadows, as I am lain down

Sketches, the inkpot far away

Sketches, moving around

My bed

cold airflow

high flow

pressure on my neck

pressure of their hands

moving galaxies

load

weight

burden.

This line launched by fate

Traced by droplets-

I have not drawn it 
It has appeared under my paint brush

I have no rubber, no watercolour

To blend and soften with

I start to dissipate

Capillary refilling time: $>2$ seconds

fingertips: black

cartoonist: white

Hypoxia

Is my central line an inkpot?

Am I drained? I have a plot

Storylines converge in wards.

My lungs resemble branches

Upon branches, trees from a Silent hill

From a disturbing path.

Ground glass

Looking through, blurred as a prognosis.

My veins could have collapsed on

A bridge, a cloth of platelets.

I imagine many book endings:

Dawn of the dead

Eighty days in bed

Outbreaks around the world (in eighty days)

Me, stuck. Eighty days.

I cannot write their names,

But ghosts made of flesh 
and blood,

Fears despite masks,

Logic despite margin of error,

Tears without fault

Need no name.

But I'm starting to flourish once more;

I feel it in my roots.

I've been growing

Since I got out of intensive care.

I'll restart my drawing.

I've drawn for a lifetime;

I'll get up and keep drawing.

I will breathe life into my work;

I've had enough of death.

It's what I do best.

They'll bring me a pencil tomorrow

I'll start planning, sketching, outlining blooms

Poppies' blooms.

Authors' contributions Each author contributed equally to this manuscript.

Publisher's Note Springer Nature remains neutral with regard to jurisdictional claims in published maps and institutional affiliations. 